Chirurgia (2019) 114: 152-161

No. 2, March - April

Copyright@ Celsius

http://dx.doi.org/10.21614/chirurgia.114.2.152

\title{
The Immunoscore in the Clinical Practice of Patients with Colon and Rectal Cancers
}

\author{
Guy Zeitoun ${ }^{1,2}$, Carine El Sissy ${ }^{2,3}$, Amos Kirilovsky ${ }^{2,3}$, Gabriela Anitei ${ }^{4}$, Anna-Maria Todosi ${ }^{4}$, Florence Marliot ${ }^{2,3}$, \\ Nacilla Haicheur ${ }^{2}$, Christine Lagorce ${ }^{3,5}$, Anne Berger ${ }^{1,5}$, Franck Zinzindohoué1, Jérome Galon ${ }^{3}$, Viorel Scripcariu ${ }^{4}$, \\ Franck Pagès ${ }^{2,3}$
}

${ }^{1}$ Service of General and Digestive Surgery, Georges-Pompidou European Hospital, AP-HP Paris, France 'Laboratory of Immunology, Immunomonitoring Platform, Georges-Pompidou European Hospital, AP-HP Paris, France ${ }^{3}$ INSERM U872, Team 15INSERM, Laboratory of Integrative Cancer Immunology, Cordeliers Research Center Paris, France ${ }^{4}$ I-st Surgical Unit, Regional Institute of Oncology, "Grigore T. Popa" University of Medicine and Pharmacy lasi, Romania ${ }^{5}$ Pathology Department, Georges-Pompidou European Hospital, AP-HP Paris, France

Corresponding author:

Pr. Franck Pagès

Immunomonitoring Platform

Laboratory of Immunology

Hôpital Européen Georges Pompidou 75015 Paris, France

E-mail: franck.pages@aphp.fr

\section{Abbreviations:}

CML - Chronic myeloid leukemia;

CIN - chromosomal instability;

MSI - micro-satellite instability;

IDEA - International Duration Evaluation of Adjuvant therapy;

nCRT - neoadjuvant chemoradiotherapy;

TME - total mesorectal excision;

W\&W - watch-and-wait;

Received: 03.03.2019

Accepted: 07.04.2019

\section{Rezumat}

Imunoscorul în practica clinică a pacienților cu cancer de colon și rect

În echilibrul perfect dintre invazia tumorală şi sistemele noastre de apărare, rolul jucat de răspunsul imun adaptiv la nivel tumoral este critic. Dincolo de faptul că toate elementele sistemului imun ce intervin în răspunsul imun înnăscut şi cel adaptativ pot fi observate la diferite grade în micromediul tumoral, se pare că există o densitate crescută de limfocite cu memorie T citotoxice, în contextul unei orientări imune Th1 la nivel intratumoral şi al frontului de invazie tumorală, ce oferă un marker de prognostic de importanță majoră în cancerul colorectal şi în tumorile solide în general. Înțelegerea rolului pe care imunitatea îl are în cancer, în urma unui secol de intensă cercetare, a condus la o schimbare completă a paradigmei. Pentru a arăta impactul major al acestui concept revoluționar, vom evidenția aici prin exemplul cancerului colorectal, cum un test imun eficient şi anume "Immunoscore" a fost dezvoltat. De asemenea, oferim date actualizate care demonstrează capacitatea Immunoscorului de a prezice $\mathrm{cu}$ o acuratețe superioară stadializării TNM evoluția clinică a pacienților şi ghidarea strategiilor terapeutice.

Cuvinte cheie: imunitate, Imunoscore, prognostic 


\begin{abstract}
In the fine balance between tumor invasion and our defensive systems, the role played by the adaptive immune response at the tumor site is critical. Beyond the fact that all the immune components of the innate and adaptive response can be observed to varying degrees in the tumor microenvironment, it appears that a high density of $\mathrm{T}$ cytotoxic and memory lymphocytes, in a context of Th1 immune orientation in the tumor and its invasion front, provides a prognostic marker of paramount importance for colorectal cancer and more generally all solid tumors. The understanding of the role of immunity in cancer, tailored during one century of intensive research, has led to a complete paradigm shift. In order to show the major impact of this conceptual revolution, we herein retrace through the example of colorectal cancer, how an effective immune test, namely the "Immunoscore", has been developed. We also provide up to date data demonstrating the capacity of the Immunoscore to prognosticate with a better accuracy than the TME classification clinical outcomes and to guide therapeutic strategies.
\end{abstract}

Key words: immunity, Immune, prognostic

\section{Introduction}

Over the last twenty years, oncology has undergone two conceptual revolutions that have changed our vision of cancer and eventually its definition. The first revolution was genomic resulting from an international research of unprecedented intensity and cost which focused on the genome of cancer cells and its molecular production (transcriptome, proteome). Major information was obtained leading to the emergence of the so-called "targeted therapies" and "molecular biomarkers" predicting the potential benefit of a specific therapy for a given patient. The second ongoing revolution consists in taking into account the tumor microenvironment as an integral part of the tumor process. Nowadays, cancer is no longer defined according to a cellular-centered vision and the lost of cancer cells homeostasis but according to an holistic tumoral vision taking into account its micro-environment composed by a set of communicating cellular compartments and the lost of this micro-environment homeostasis. This new paradigm has not only modified our perception of the factors influencing cancer progression but also the evaluation of its prognostic and the development of adapted therapeutic strategies. For the first time, by highlighting the major role of the immune system in the evolution of cancer, the selfdefense skills of a patient is taken into account. This new vision places the patient rather than the tumor at the center of the prognostic and therapeutic reflections.

\section{What is Cancer?}

This issue, still present (1), underlines the importance of the conceptual framework in which a research evolves. In oncology, the prevailing paradigm over the last fifty years was that cancer resulted from the accumulation of a limited number of "key" gene mutations involved in cell survival and proliferation. This vision of cancer is cellular-centered and genoguided. According to this vision, the occurrence of "random" alterations of the genome of a cell can induce irreversible changes in its behavior regardless of the environment in which this cell evolves. The clinical corollary of this vision was the so-called "gene therapy", which is the possibility to treat a tumor by "restoring the wild gene" or by "blocking the mutated gene" (2). Chronic myeloid leukemia (CML) is a typical illustration of this vision. In 1960, the discovery of the Philadelphia chromosome, translocation t $(9 ; 22)$ (q34; q11), demonstrated that this pathology, systematically fatal in five years, was due to a single genetic alteration (3). 
The development of Imatinib, blocking the effects of the chimeric BCR-ABL protein produced by the translocation, has since radically transformed the prognosis of CML (4).

For solid tumors, it thus seemed indisputable that the clinical course of cancer was punctuated by a limited number of mutations occurring in a given chronological order. This vision has been perfectly illustrated by the well-known publication of Vogelstein et al. and its graphic representation further nicknamed the "Volgogramme" (5). However, this genomic approach of the "cellular-centered genoguided" paradigm eventually showed its limits (6). From a prognostic point of view, no gene or genomic signature demonstrated any capacity to optimizing the prognostic value of the 70 years old histopathological classification (TNM classification) $(7,8)$. Therapeutically in most instances, the targeted treatments, only allowed a modest and limited in time slowdown of tumor progression $(9,10)$. One of the essential reasons for this limited efficacy is the extreme diversity and variability of genomic alterations, as revealed by the recent high-throughput genomic analysis techniques (11). For example, each tumor cell of colorectal tumors contains up to 11,000 genomic alterations (12). We now know that genomic alterations are due to genomic instability resulting from a shift in the behavior of mechanisms regulating the genome. Three categories of genomic instability have been identified (13). The former is characterized by chromosomal instability (CIN) and associates frequent mutations of key genes such as TP53, APC, KRAS and PI3 kinase (PIK3CA). The second is characterized by genetic instability, linked to the alteration of the DNA repair system resulting in micro-satellite instability (MSI). The third is characterized by epigenomic instability at imprinting control regions due to DNA methylation level changes resulting in gene dysregulation (14). Although the understanding of these mechanisms are of major scientific interests, currently, only the presence of a high genetic instability in cancer cells (the so-called High-MSI tumors) has been associated to a better prognosis (15). In colorectal cancer, only a minority of tumors is High-MSI and their rates are location-dependent falling down from $20 \%$ in the right colon to $3 \%$ in the rectum. Of note, if High-MSI tumors in colorectal cancer have been repeatedly associated with a better prognosis, it has been recently show that recurrence patterns differ in these patients (i.e. more frequent local recurrence or peritoneal metastasis and less frequent lung or liver metastases) and that once a recurrence occurs the prognosis is worse $(15,16)$. This new information illustrates the difficulty to find prognostic markers at a molecular level.

At the very end of the second millennium, Hanahan and Weinberg noted the inability of the cell-centered geno-guided vision to be structuring, that is, to provide a satisfying explanatory and applicative framework (17). These authors pledged for a "Copernican revolution" by no longer defining the cancer cell phenotype through the acquisition of key genomic alterations, but through the acquisition of key behaviors due to genomic changes. Six acquired hallmarks that could be independently expressed were disclosed: i) selfsufficiency in growth signals, ii) insensitivity to growth-inhibitory (antigrowth) signals, iii) evasion of programmed cell death (apoptosis), iv) limitless replicative potential, v) sustained angiogenesis, and vi) tissue invasion and metastasis. But this "revolution" really made sense when in 2011, these same authors added two new characteristics: vii) ability to reprogram its energy metabolism (Warburg effect); and viii) ability to evade immune surveillance (18). Beyond the recognition of the essential role of the immune system in the evolution of cancer, this article marked a conceptual breakthrough since the cell-centered vision was replaced de facto by a holistic vision including the environment as a major actor in the occurrence, evolution and therefore the definition of a cancer. Cancer was no longer defined solely by its cancer cells, but by cancer cells and their microenvironment (19). The microenvironment includes all cellular compartments associated with cancer cells: vascular, neuroendocrine, stromal, epithelial, and immune compart- 
ments. These compartments form a heterogeneous, dynamic and communicative structure. This new definition of the tumor sphere will with no doubt evolve in the next future by integrating the microbiote (20).

\section{Immunology and Cancer}

Strikingly, the role of both the immune system and the genome in cancer has been considered at the beginning of the $\mathrm{XX}^{\text {th }}$ century (1). In 1909, Paul Ehrlich was the first to postulate that the immune system was involved in controlling the tumor process by eliminating objoblabnormal cells from cell divisions. This hypothesis was based on clinical observations, such as that reported by William B. Cooley, showing a correlation between tumor regressions and the occurrence of streptococcal infection. The inflammatory reaction secondary to over-infection seemed to promote cancer control. But it was only in 1970, that Burnett tailored the concept of immunosurveillance (21). Immunosurveillance was defined as the ability of the immune system to recognize and destroy abnormal cells preventing the emergence of cancer. After a long period of controversy and dormancy, this concept eventually experienced a new resurgence the beginning of the century through the formal demonstration of a greater incidence of spontaneous cancers and tumors induced in mice deficient in genes or immune cells (22). Immunosurveillance is currently integrated into a larger theory called "immunoediting", taking into account the interactions between cancer cells and cells of the immune system, each influencing and modifying the behavior of the other in a bidirectional cross-talk (23). Three chronologically distinct stages are individualized: the elimination stage, followed by an equilibrium stage during which the cancer cells are "dormant" for a period that can be very long before the occurrence of the escape stage (23). Throughout this process, the immune system exerts an immune surveillance, creating a selective pressure leading to the emergence of immune-resistant tumor clones that parallel the progressive switch from an immune cyto- toxic response to an immune tolerance. It is only during this "escape phase" that the tumor mass becomes symptomatic and leads the patient to consult.

\section{From Research to Clinic}

Conceptual revolutions are often based on technological revolutions. As the scientific and medical approaches proceed by the mean of observation, each technological revolution disrupting our means of observation suddenly increases our level of precision leading to the opportunity to disclose new criteria of discrimination and new classification systems (24). During the last decades, the major advents in imaging, computation, and nanotechnologies have allowed to develop new biomarkers, digital pathology and image analysis that provided objective and robust assessments of cellular components within solid tumors. These new technologies permitted to better observe the immune system within the tumor, to better understand its role in the dynamic of cancer and eventually develop an original tool, namely the Immunoscore (25-28).

\section{Elaboration of the Immunoscore}

In many solid tumors such as colorectal cancer, a strong immune infiltration of the tumor has been associated with prolonged survival (27). Specifically, a high infiltration of CD3 +, CD8 + CD4 + T lymphocytes and $\mathrm{CD} 45 \mathrm{RO}+\mathrm{T}$ cells, localized in the core and the margin of the tumor, has been correlated with an increased of disease-free survival (DFS) and overall survival (OS). This type of infiltration is associated with an immune orientation of type 1 (Th1) CD4 + T lymphocytes that promote activation of CD8 T cells. These lymphocytes express chemokine receptors and specific adhesive molecules playing a major role in the mobilization of these cells at the tumor site. The confirmation of the prognostic impact of the immune component of tumors on large retrospective cohorts led to the development of a simple, powerful and robust test called "Immunoscore" (I) (28). This test is 
performed by an immunohistochemistry technique on tissue section coupled to an image analysis system. Its principle is based on the determination of the density of two lymphocyte populations (CD3 / CD8) in both the core and the margin of the tumor. The obtained data allow an evaluation of the Immunoscore from 0 (I0), reflecting a low density of the two cell types in both regions, to 4 (I4) reflecting a high density of the two types of cells in both regions. The prognostic value of the Immunoscore has been demonstrated in colorectal cancer at all stages of pathological classification. In multivariate analysis, the prognostic value of the Immunoscore appears to be greater than that provided by the TNM classification and the constitutive factors of TNM appear to be dependent on Immunoscore. Strikingly, the intra-tumoral adaptive immune component evaluated by the Immunoscore allows discriminating with high statistical confidence the patients at risk of recurrence even at early stages of tumoral development (Stage I-II) (29).

\section{Immunoscore as a new component of a TNM-Immune classification of colon cancer}

To validate these results and allow the introduction of immune parameters into cancer classification, an international consortium of 14 centers from 13 countries located in North America, Europe, and Asia, led by the Society for Immunotherapy of Cancer, decided to assess the Immunoscore assay in patients with TNM stage I-III colon cancer (30). In this study, the densities of CD3+ and CD8+ T cells in colon tumor and invasive margin regions were determined using a specially developed Immunoscore module that was integrated into the image-analysis system of a Developer XD digital pathology software (Definiens, Munich, Germany). The recently published results, based on 3539 patients confirmed that Immunoscore assay segregated patients into sub- categories with significant $(p<0 \cdot 0001)$ differences for time to recurrence, disease-free survival, and overall survival (31). Patients with a high Immunoscore had significantly the lowest risk of recurrence at 5 years $(8 \%)$ as compared to patients with intermediate Immunoscore (19\%) and patients with a low Immunoscore (32\%). Using a stratified Cox multivariable analysis, the Immunoscore association with time to recurrence was confirmed to be independent of patient age, sex, T stage, $\mathrm{N}$ stage, microsatellite instability, and existing prognostic factors $(p<0 \cdot 0001)$. Moreover, the Immunoscore was confirmed to have the highest relative contribution to the risk of all clinical parameters, including the American Joint Committee on Cancer and Union for International Cancer Control TNM classification system. Besides the confirmation of the prognostic value of the Immunoscore in colon cancer, this study allowed to definitively freeze the so-called "consensus Immunoscore" where the mean of four percentiles (two markers, two regions) was calculated and converted into an Immunoscore (Fig. 1). In a three-category Immunoscore analysis, a 0-25\% density was scored as low, a density between $25 \%$ and $70 \%$ was scored as intermediate, and a density between $70 \%$ and $100 \%$ density was scored as high. Using this "consensus Immunoscore", it will be now important to validate the standardized Immunoscore assay and determine its prognostic value and prediction of chemotherapy response in randomized clinical trials with stage II or stage III colon cancer patients treated with adjuvant chemotherapy (e.g. N0147 trial, International Duration Evaluation of Adjuvant therapy (IDEA) collaboration). Moreover, the IDEA collaboration was established to prospectively combine and analyze data from several randomized trials conducted around the world to answer whether reduction of adjuvant treatment duration may decrease toxicities without loss of efficacy in stage III colon cancer. This could offer clear advantages to patients and health care providers (32). By using the TNM classification, IDEA France, as part of the IDEA international collaboration, in which $90 \%$ of patients received mFOLFOX6, shows superiority of 6 months of adjuvant chemotherapy compared with 3 months, especially in 

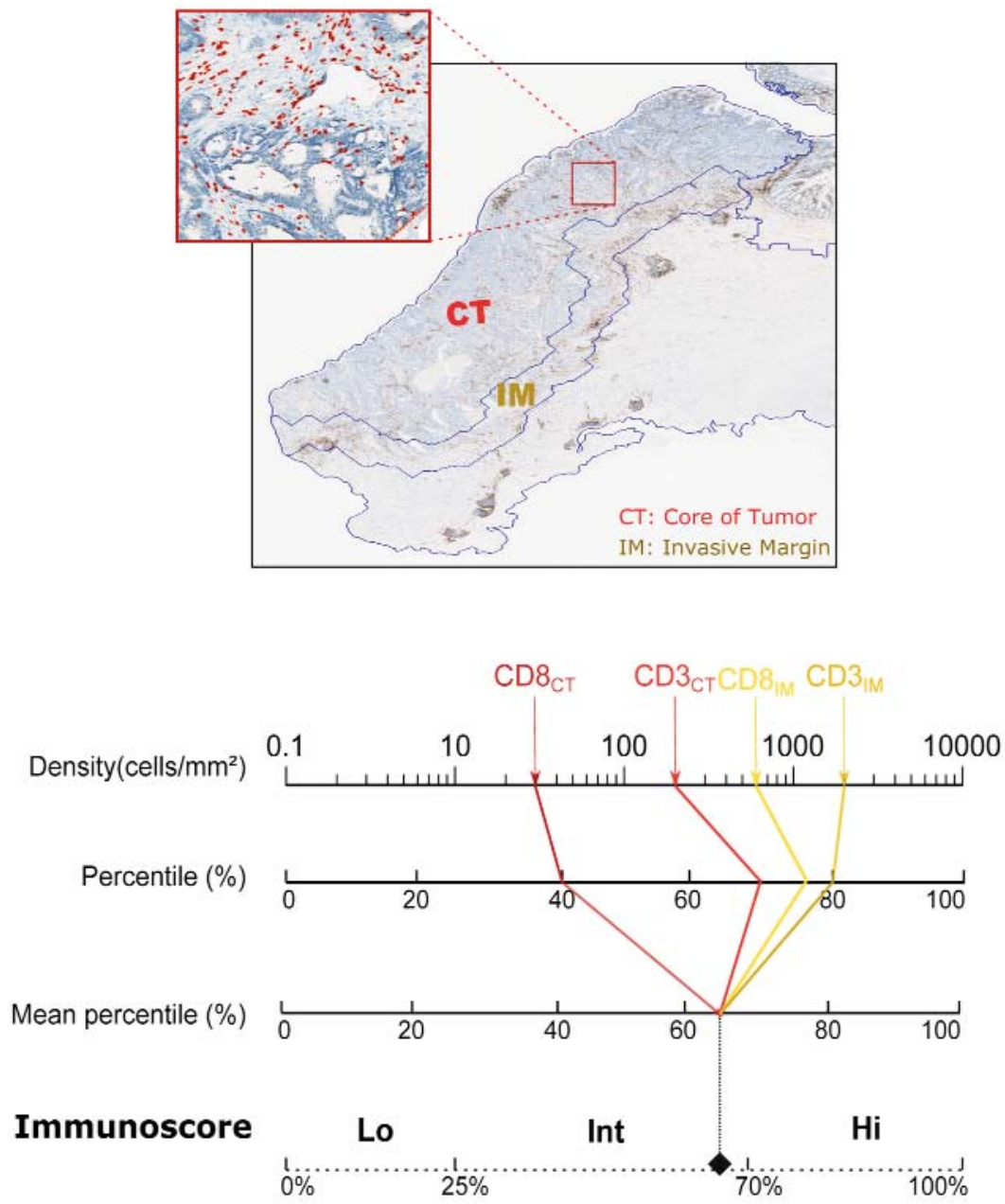

Figure 1. Chart illustrating the IS calculation method. Densities of CD3CT, CD3IM, CD8CT, and CD8IM are reported and converted into percentile values, determined by the international validation study (Pagès $\mathrm{F}$ et al, The Lancet 2018). The mean percentile of the 4 markers is calculated to generate the IS percentile value and translated into a 3-category scoring system IS High (Hi), IS Intermediate (Int) and IS Low (Lo).

the T4 and/or N2 subgroups (33). In this setting, the Immunoscore provides a new approach of categorization that could disclose a subgroup of patients eligible for a reduced chemotherapy regimen (i.e. IS High) (34). Indeed, this study is on the way.

Beyond localized cancers, the relevance of the Immunoscore could be extended to metastatic disease as the Immunoscore has been shown to identify tumors that are likely to metastasize and to predict the prognosis of patients with metastases from primary colon cancer (35). Treatment of patients with metastatic colon cancers is still challenging.
Only a fraction of these patients respond to immune checkpoint inhibitors (ICI). As responders are more likely to be defective in mismatch repair genes (MSI+), only MSI + colon cancer stage IV patients are to date eligible to ICI. Keeping in mind first, that MSI+ patients are over-represented in the group of tumors with high densities of CD8 T-cells; and second, that patients with High T-cell infiltration have a higher expression of PD-1 and PDL1, and are more likely to respond to ICI; these observations suggest that the response to ICI is strongly dependent on the presence of an established in situ 
adaptive immune reaction $(36,37)$. We thus questioned, as suggested by Le \& al. whether taking into account the evaluation of the in situ immune reaction in the primary tumor together with MSI status could clarify and extend the range of patients eligible to ICI (38). Data of 1579 UICC-TNM stage I/II/III patients with available MSI status were extracted from the Immunoscore international validation study out of which 318 patients $(20 \%)$ experienced a relapse $(31,39)$. Combining MSI+ status ( $\mathrm{n}=36$ metastatic patients; $11 \%$ of MSI patients) with IS high $(n=33$ metastatic patients; $11 \%$ of MSS patients) to select patients for ICI could extend from $11 \%$ to $22 \%$ the patients eligible to such immunotherapy (39).

\section{Immunoscore as a new component of a TNM-Immune classification of rectal cancer}

Initial analyses were performed on both colon and rectal cancers. However, marked anatomical, physiological, biological, and therapeutic differences exist between colon and rectum. We thus assessed and confirmed on a series 111 rectal cancers, primarily treated by primary surgery, that the Immunoscore could be a useful prognostic marker in patients with rectal cancer.

However, in contrast to colon cancer, rectal cancer is characterized by a high risk of local recurrence $(40,41)$. As a result, while for colon cancers a complete resection of the tumor is recommend at any stage as the first step of the therapeutic strategy, in rectal cancer primary surgery is only recommended for a minority of patients. For the majority of rectal cancer (i.e. T3-T4 mid- and low-rectal cancers or for all tumors that are located one $\mathrm{mm}$ or less from the fascia recti whatever the site and stage of the tumor) international guidelines recommend neoadjuvant chemoradiotherapy (nCRT) followed by protectomy with total mesorectal excision (TME) (42). Moreover, for patients with clinical complete response to nCRT, a watch-and-wait (W\&W) approach has been proposed to avoid the morbidity of conventional surgery $(43,44)$. Thus, in most instances in rectal cancer, the tumor is either altered by the nCRT or not available precluding the performance of an Immunoscore as described and validated for colon cancer.

For this reason, we questioned whether in rectal cancer treated by $\mathrm{nCRT}$, the in situ immune cell infiltrate of tumors could be evaluated on biopsies performed at the time of diagnosis. The rationale of this proposal is that among the different surrogate markers explored to predict response to nCRT, two major arguments favor the use of in situ immune cell infiltrate of tumors. First, ionizing radiation has the capacity to prime/reinforce an adaptive T-cell mediated immune response which acts in the mechanisms of local tumor regression and of distant tumor inhibition and rejection (i.e. the abscopal effect) $(45,46)$. Second, preliminary studies have suggested that in situ immune cell infiltrate of tumors could be evaluated on biopsies performed at the time of diagnosis (4749). Third, by using more accurate classifications, oncologic outcomes has been recently shown to significantly correlate with pathological response to nRCT (50). For long, the major impact of nCRT on local recurrence has highly contrasted with the absence of any demonstrated benefit on overall survival or disease specific survival (51). Prediction of individual response to $\mathrm{nCRT}$ is thus now of paramount importance (52). For poor responders, other combination of therapies should be explored $(53,54)$. For intermediate responders, adjunction of therapies potentiating the effect of nCRT could positively impact patients' outcome (55). For good responders, less invasive strategies such as local excision, or a wait and watch (W\&W) approach could reduce or even avoid surgical side-effects and increase quality of life $(43,44,56,57)$.

In a short preliminary series of patients $(n=55)$ we showed that the determination of the immune infiltrate in biopsies performed at the time of diagnosis could be valuable information for the prediction of response to nCRT (49).

This prompted us to assess whether the quality and the intensity of the natural adaptive immune response at tumor site, evaluated by a biopsy-adapted Immunoscore (ISB), could influence both the response to nCRT and the clinical outcomes. In a submitted publication, 
we observed that ISB strongly increased the predictive accuracy of very good responders (ypTNM 0-1) assessed by imaging post-nCRT (58). This could be of particular interest since an accurate prediction of pathologic complete response is the prerequisite for considering preservative strategies. Further, ISB stratified patients into groups (i.e. High, Intermediate, Low) with significant differences for occurrence of local and distant recurrence. This probably account for the capacity of the immune response to disseminate through the body leading, beyond its local action, to a systemic impact (i.e. the abscopal effect) and to persist through memory cells that can eradicate or maintain an equilibrium with tumors cells (59). Notably, ISB contributed more than cTNM, ycTNM and tumor location to predict time to recurrence (TTR). All these findings suggested the potential utility of the ISB to frame the therapeutic decision of conservative surgery. To date however, the main concern restricting the extent of the W\&W strategy is local relapse (often referred as local regrowth) that develops during the first 12 months period (60). In a limited multicenter series of patients treated by W\&W, we observed that almost one-third of them presented with a ISB High. In our series of patients managed by W\&W, none of the ISB High patients experienced a local relapse (often referred as local regrowth) during a period of at least 12 months.

\section{Conclusion}

The reproducibility and robustness of the consensus Immunoscore as a strong prognostic factor in association with the TNM classification system favors its implementation as a new component in the classification of colon and rectal cancers when surgery is the first line treatment. For patients treated by a neoadjuvant therapy, the ISB seems to be a good surrogate of the Immunoscore. Indeed, the next step is now to validate the clinical utility the ISB in a large-scale prospective study. This work is underway with the OPERA clinical trial (NCT02505750). After one century of research all over the world in the field of immuno- oncology, a new clinical breakthrough could occur in a very next future with the ability for a given patient to evaluating his immune system and to "personalizing" his therapeutic strategy.

\section{Conflict of Interest}

The authors declare no conflicts of interests.

\section{Author's Contributions}

All authors were involved in conceving the manuscript.

\section{References}

1. Prendergast GC.Immunological thought in the mainstream of cancer research: Past divorce, recent remarriage and elective affinities of the future. Oncoimmunology. 2012;1(6):793-797.

2. Cline MJ, Stang H, Mercola K, Morse L, Ruprecht R, Brown J, et al. Gene transfer in intact animals. 1980;284(5755):422-5.

3. Nowell P, Hungerford D. A minute chromosome in human chronic granulocytic leukemia (abstract). Science. 1960;132:1497.

4. O'Brien SG, Guilhot F, Larson RA, Gathmann I, Baccarani M, Cervantes F, et al. IRIS Investigators. Imatinib compared with interferon and low-dose cytarabine for newly diagnosed chronic-phase chronic myeloid leukemia. N Engl J Med. 2003;348(11):994-1004.

5. Vogelstein B, Fearon ER, Hamilton SR, Kern SE, Preisinger AC, Leppert $\mathrm{M}$, et al. Genetic alterations during colorectal-tumor development. N Engl J Med. 1988;319(9):525-32.

6. Folkman J, Hahnfeldt P, Hlatky L. Cancer: looking outside the genome. Nat Rev Mol Cell Biol. 2000;1(1):76-9.

7. Dukes C. The classification of cancer of the rectum. J Pathol Bacteriol. 1932;35:323-332.

8. Denoix PF. Enquête permanente dans les centres anticancéreux. Bull Inst Nat Hyg. 1946;1:70-5.

9. Amit L, Ben-Aharon I, Vidal L, Leibovici L, Stemmer S. The impact of Bevacizumab (Avastin) on survival in metastatic solid tumors--a meta-analysis and systematic review. PLoS One. 2013;8(1):e51780.

10. Palumbo MO, Kavan P, Miller WH Jr, Panasci L, Assouline S, Johnson N, et al. Systemic cancer therapy: achievements and challenges that lie ahead. Front Pharmacol. 2013 May 7;4:57.

11. Vogelstein B, Papadopoulos N, Velculescu VE, Zhou S, Diaz LA Jr, Kinzler KW. Cancer genome landscapes. Science. 2013;339(6127): 1546-58.

12. Stoler DL, Chen N, Basik M, Kahlenberg MS, Rodriguez-Bigas MA, Petrelli NJ, et al. The onset and extent of genomic instability in sporadic colorectal tumor progression. Proc Natl Acad Sci U S A. 1999;96(26):15121-6.

13. Kim RY, Xu H, Myllykangas S, Ji H. Genetic-based biomarkers and next-generation sequencing: the future of personalized care in colorectal cancer. Per Med. 2011;8(3):331-345.

14. Kim J, Bretz CL, Lee S. Epigenetic instability of imprinted genes in human cancers. Nucleic Acids Res. 2015;43(22):10689-99.

15. Popat S, Hubner R, Houlston RS. Systematic review of microsatellite instability and colorectal cancer prognosis. J Clin Oncol. 2005;23(3): 609-18.

16. Kim CG, Ahn JB, Jung M, Beom SH, Kim C, Kim JH, et al. Effects of microsatellite instability on recurrence patterns and outcomes in colorectal cancers. Br J Cancer. 2016;115(1):25-33. 
17. Hanahan D, Weinberg RA. The hallmarks of cancer. Cell. 2000; 100(1):57-70.

18. Hanahan D, Weinberg RA. Hallmarks of cancer: the next generation. Cell. 2011;144(5):646-74.

19. Sonnenschein C, Soto AM. The death of the cancer cell. Cancer Res. 2011;71(13):4334-7.

20. Maynard CL, Elson CO, Hatton RD, Weaver CT. Reciprocal interactions of the intestinal microbiota and immune system. Nature. 2012;489:231-41.

21. Burnet FM. The concept of immunological surveillance. Prog Exp Tumor Res. 1970;13:1-27.

22. Dunn GP, Old LJ, Schreiber RD. The three Es of cancer immunoediting. Annu Rev Immunol. 2004;22:329-60.

23. Schreiber RD, Old LJ, Smyth MJ. Cancer immunoediting: integrating immunity's roles in cancer suppression and promotion. Science. 2011;331(6024):1565-70.

24. Longo DL. Tumor heterogeneity and personalized medicine. N Engl J Med. 2012;366(10):956-7.

25. Pagès F, Berger A, Camus M, Sanchez-Cabo F, Costes A, Molidor R, et al. Effector memory $T$ cells, early metastasis, and survival in colorectal cancer. N Engl J Med. 2005;353(25):2654-66.

26. Galon J, Costes A, Sanchez-Cabo F, Kirilovsky A, Mlecnik B, Lagorce-Pagès $C$, et al. Type, density, and location of immune cells within human colorectal tumors predict clinical outcome. Science. 2006;313(5795):1960-4.

27. Fridman $W H$, Pagès $F$, Sautès-Fridman $C$, Galon J. The immune contexture in human tumours: impact on clinical outcome. Nat Rev Cancer. 2012;12(4):298-306.

28. Mlecnik B, Tosolini M, Kirilovsky A, Berger A, Bindea G, Meatchi T, et al. Histopathologic-based prognostic factors of colorectal cancers are associated with the state of the local immune reaction. J Clin Oncol. 2011;29(6):610-8.

29. Pagès $F$, Kirilovsky A, Mlecnik B, Asslaber M, Tosolini M, Bindea G, et al. In situ cytotoxic and memory $T$ cells predict outcome in patients with early-stage colorectal cancer. J Clin Oncol. 2009; 27(35):5944-51.

30. Galon J, Pagès F, Marincola FM, Angell HK, Thurin M, Lugli $A$, et al Cancer classification using the Immunoscore: a worldwide task force. J Transl Med. 2012 Oct 3;10:205.

31. Pagès $F$, Mlecnik $B$, Marliot $F$, Bindea $G$, Ou FS, Bifulco $C$, et al. International validation of the consensus Immunoscore for the classification of colon cancer: a prognostic and accuracy study. Lancet. 2018 May 26;391(10135):2128-2139.

32. André T, Iveson T, Labianca R, Meyerhardt JA, Souglakos I, Yoshino T, et al. The IDEA (International Duration Evaluation of Adjuvant Chemotherapy) Collaboration: Prospective Combined Analysis of Phase III Trials Investigating Duration of Adjuvant Therapy with the FOLFOX (FOLFOX4 or Modified FOLFOX6) or XELOX (3 versus 6 months) Regimen for Patients with Stage III Colon Cancer: Trial Design and Current Status. Curr Colorectal Cancer Rep. 2013;9:261-269.

33. André T, Vernerey D, Mineur L, Bennouna J, Desrame J, Faroux R, et al. Three Versus 6 Months of Oxaliplatin-Based Adjuvant Chemotherapy for Patients With Stage III Colon Cancer: Disease-Free Survival Results From a Randomized, Open-Label, International Duration Evaluation of Adjuvant (IDEA) France, Phase III Trial. J Clin Oncol. 2018;36(15): 1469-1477.

34. Grothey A, Sobrero AF, Shields AF, Yoshino T, Paul J, Taieb J, et al. Duration of adjuvant chemotherapy for stage III colon cancer. N Engl J Med. 2018;378(13):1177-1188.

35. Mlecnik B, Bindea G, Kirilovsky A, Angell HK, Obenauf AC, Tosolini $\mathrm{M}$, et al. The tumor microenvironment and Immunoscore are critical determinants of dissemination to distant metastasis. Sci Transl Med. $2016 ; 8(327): 327$ ra26.

36. Overman MJ, McDermott R, Leach JL, Lonardi S, Lenz HJ, Morse MA, et al. Nivolumab in patients with metastatic DNA mismatch repair-deficient or microsatellite instability-high colorectal cancer
(Check Mate 142): an open-label, multicentre, phase 2 study. Lancet Oncol. 2017;18(9):1182-1191.

37. Mlecnik B, Bindea G, Angell HK, Maby P, Angelova M, Tougeron D, et al. Integrative Analyses of Colorectal Cancer Show Immunoscore Is a Stronger Predictor of Patient Survival Than Microsatellite Instability. Immunity. 2016; 44(3):698-711.

38. Le DT, Hubbard-Lucey VM, Morse MA, Heery CR, Dwyer A, Marsilje $\mathrm{TH}$, et al. A Blueprint to Advance Colorectal Cancer Immunotherapies. Cancer Immunol Res. 2017;5(11):942-949.

39. J. Galon, B. Mlecnik, F. Hermitte, F. Marliot, C. Bifulco, A. Lugli, \& al. MSI status plus Immunoscore to select metastatic colorectal cancer patients for immunotherapies. ESMO 2018 (Abstract)

40. Phillips RK, Hittinger R, Blesovsky L, Fry US, Fielding LP. Local recurrence following 'curative' surgery for large bowel cancer. I. The overall picture. Br J Surg. 1984;71(1):12-6.

41. Kapiteijn E, Marijnen CA, Colenbrander AC, Klein Kranenbarg E, Steup WH, van Krieken JH, et al. Local recurrence in patients with rectal cancer, diagnosed between 1988 and 1992: a populationbased study in the west Netherlands. Eur J Surg Oncol. 1998; 24(6):528-35.

42. Nielsen LB, Wille-Jørgensen P. National and international guidelines for rectal cancer. Colorectal Dis. 2014;16(11):854-65.

43. Habr-Gama A: Assessment and management of the complete clinical response of rectal cancer to chemoradiotherapy. Colorectal Dis. 2006;8:21-24.

44. Renehan AG, Malcomson L, Emsley R, Gollins S, Maw A, Myint AS, et al: Watch-and-wait approach versus surgical resection after chemoradiotherapy for patients with rectal cancer (the OnCoRe project): a propensity-score matched cohort analysis. Lancet Oncol. 2016;17(2):174-183.

45. Demaria S, Ng B, Devitt ML, Babb JS, Kawashima N, Liebes L, et al: Ionizing radiation inhibition of distant untreated tumors (abscopal effect) is immune mediated. Int J Radiat Oncol Biol Phys. 2004;58(3):862-70.

46. Chajon E, Castelli J, Marsiglia H, De Crevoisier R. The synergistic effect of radiotherapy and immunotherapy: A promising but not simple partnership. Crit Rev Oncol Hematol. 2017;111:124-132.

47. Yasuda K, Nirei T, Sunami E, Nagawa H, Kitayama J. Density of CD4(+) and CD8(+) T lymphocytes in biopsy samples can be a predictor of pathological response to chemoradiotherapy (CRT) for rectal cancer. Radiat Oncol. 2011;6:49.

48. Shinto E, Hase K, Hashiguchi Y, Sekizawa A, Ueno H, Shikina A, et al: CD8+ and FOXP3+ Tumor-Infiltrating T Cells Before and After Chemoradiotherapy for Rectal Cancer. Ann Surg Oncol. 2014;21 Suppl 3:S414-21.

49. Anitei MG, Zeitoun G, Mlecnik B, Marliot F, Haicheur N, Todosi AM, et al: Prognostic and predictive values of the immunoscore in patients with rectal cancer. Clin Cancer Res. 2014;20(7):1891-9.

50. Park IJ, You YN, Agarwal A, Skibber JM, Rodriguez-Bigas MA, Eng $C$, et al. Neoadjuvant treatment response as an early response indicator for patients with rectal cancer. J Clin Oncol. 2012;30(15): 1770-6.

51. De Caluwé L, Van Nieuwenhove Y, Ceelen WP. Preoperative chemoradiation versus radiation alone for stage II and III resectable rectal cancer. Cochrane Database Syst Rev. 2013;(2): CD006041.

52. Ryan JE, Warrier SK, Lynch AC, Ramsay RG, Phillips WA, Heriot AG. Predicting pathological complete response to neoadjuvant chemoradiotherapy in locally advanced rectal cancer: a systematic review. Colorectal Dis. 2016;18(3):234-46.

53. Schrag D, Weiser MR, Goodman KA, Gonen M, Hollywood E, Cercek A, et al. Neoadjuvant chemotherapy without routine use of radiation therapy for patients with locally advanced rectal cancer: a pilot trial. J Clin Oncol. 2014 Feb 20;32(6):513-8.

54. Cassidy RJ, Liu Y, Patel K, Zhong J, Steuer CE, Kooby DA, et al. Can we eliminate neoadjuvant chemoradiotherapy in favor of neoadjuvant multiagent chemotherapy for select stage II/II rectal 
adenocarcinomas: Analysis of the National Cancer Data base. Cancer. 2017;123(5):783-793.

55. Gash KJ, Chambers AC, Cotton DE, Williams AC, Thomas MG. Potentiating the effects of radiotherapy in rectal cancer: the role of aspirin, statins and metformin as adjuncts to therapy. $\mathrm{Br} \mathrm{J}$ Cancer. 2017;117(2):210-219.

56. Garcia-Aguilar J, Renfro LA, Chow OS, Shi Q, Carrero XW, Lynn PB, et al. Organ preservation for clinical T2NO distal rectal cancer using neoadjuvant chemoradiotherapy and local excision (ACOSOG Z6041): results of an open-label, single-arm, multi-institutional, phase 2 trial. Lancet Oncol. 2015;16(15):1537-1546.

57. Shaikh I, Askari A, Ourû S, Warusavitarne J, Athanasiou T, Faiz 0. Oncological outcomes of local excision compared with radical surgery after neoadjuvant chemoradiotherapy for rectal cancer: a systematic review and meta-analysis. Int $\mathrm{J}$ Colorectal Dis 2015; 30:19-29.

58. El Sissy, Kirilovsky A, Van den Eynde M, Scripcariu DV, Musina AM, Anitei $\mathrm{G}$, et al. The Consensus Immunoscore adapted to biopsies as an indicator of response to neoadjuvant treatment and a predictor of outcome for patients with rectal cancers. Clinical significance for a "Watch and Wait" strategy. (submitted)

59. Koebel CM, Vermi W, Swann JB, Zerafa N, Rodig SJ, Old LJ, et al. Adaptive immunity maintains occult cancer in an equilibrium state. Nature. 2007;450(7171):903-7.

60. Sclafani F, Brown G, Cunningham D, Wotherspoon A, Mendes LST, Balyasnikova S, et al. Comparison between MRI and pathology in the assessment of tumour regression grade in rectal cancer. $\mathrm{Br} J$ Cancer. 2017;117(10):1478-1485. 